(C) 2019 by the Arizona Board of Regents on behalf of the University of Arizona. This is an Open Access article, distributed under the terms of the Creative Commons Attribution licence (http://creativecommons. org/licenses/by/4.0/), which permits unrestricted re-use, distribution, and reproduction in any medium, provided the original work is properly cited.

\title{
CHRONOLOGY AND PLANT UTILIZATION FROM THE EARLIEST WALLED SETTLEMENT IN THE HEXI CORRIDOR, NORTHWESTERN CHINA
}

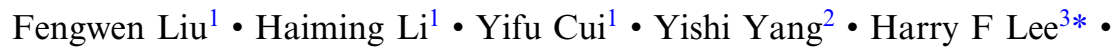 \\ Detian Ding ${ }^{4} \cdot$ Yunguang $\mathrm{Hou}^{5} \cdot$ Guanghui Dong ${ }^{1 *}$
${ }^{1}$ MOE Key Laboratory of Western China's Environmental System, College of Earth \& Environmental Sciences, Lanzhou University, Lanzhou, Gansu Province, 730000, China
${ }^{2}$ Gansu Provincial Institute of Cultural Relics and Archaeology, Lanzhou, Gansu Province, 730000, China
${ }^{3}$ Department of Geography and Resource Management, The Chinese University of Hong Kong, Shatin, New Territories, Hong Kong
${ }^{4}$ History \& Culture school of Lanzhou University, Lanzhou, Gansu Province, 730000, China
${ }^{5}$ Jinchuan Cultural Relics Administration, Jinchang, Gansu Province, 737100, China

\begin{abstract}
The development and subsistence strategies adopted in ancient settlements are crucial to the understanding of long-term human-environmental interaction in the past. Here, we reassess the chronology of the ancient walled settlement of Sanjiao in the Hexi Corridor in northwestern China through accelerator mass spectrometry radiocarbon $\left(\mathrm{AMS}{ }^{14} \mathrm{C}\right.$ ) dating and explore the subsistence of the settlers inside through the identification of carbonized seeds and charcoal. In addition, high-resolution paleoclimate records in the Hexi Corridor and nearby regions are employed to explore the reason for the construction of Sanjiao. Our results show that Sanjiao was built around 828 cal BC and remained inhabited through 384-116 cal BC. This indicates Sanjiao is the earliest known walled settlement in the Hexi Corridor. Ancient people at Sanjiao consumed crops such as barley, broomcorn millet, and foxtail millet, and used wood from Tamarix chinensis, Tamarix, Salix, Picea, Hippophae, Betulaceae, and Poaceae as fuel. The construction date of Sanjiao correlates with climate deterioration and social upheavals in the Hexi Corridor, potentially suggesting a defensive purpose for the site.
\end{abstract}

KEYWORDS: ancient walled settlement, Hexi Corridor, radiocarbon dating, subsistence strategy.

\section{INTRODUCTION}

Ancient walled settlements are considered important symbols of human civilization (Redfield and Singer 1954; Sun 1990; Wang 1995; Yan 1999; Qian 2000; Xu 2009; Gates 2011). The research of ancient walled settlements has not only revealed information about military, religion, and the economy in the past (Zuiderhoek 2016), but also provided valuable knowledge of human-environmental interaction in human history (Dong et al. 2016a). The ancient walled settlements in China are of great scientific value as China is the locus of the first empire to be established in East Asia, which has undergone gradual sociopolitical transitions from conflicting territorial states to a prosperous empire. The investigation of the ancient walled settlements in China may help understand the social evolution, rising social complexity, and the emergence of early states in East Asia.

The earliest ancient walled settlement in China appeared in the north-central region during the late Yangshao Period (3500-3000 BC) (Zhang et al. 1999). During the Longshan Period (2600 2000 BC), numerous walled settlements emerged along the Yellow River and Yangtze River valleys (Qian 2000), which indicate a dramatic transformation of social structure, possibly brought by a relatively cold and dry climate (Marcott et al. 2013; Wanger et al. 2013; Chen et al. 2015a; Hosner et al. 2016). This transformation preceded the emergence of ancient civilizations in the Xia and Shang Dynasties in the second Millenium BC. Later, the Zhou Dynasty (Western Zhou and Eastern Zhou) (1046-221 BC) witnessed a further significant change in politics, society, and scholarship. Also, conflicts became more frequent, while

\footnotetext{
*Corresponding author. Emails: harrylee@cuhk.edu.hk; ghdong@lzu.edu.cn.
} 
more walled settlements were built for the protection of inhabitants (Qian 2000). Despite the considerable academic value of ancient walled settlements in China, they remain insufficiently explored, especially those in the Hexi Corridor in northwestern China.

The ancient Silk Road played a critical role in the transcontinental cultural and technological exchanges that took place from the second millennium BC. In Chinese history, the Hexi Corridor was a crucial military node and the key section of the ancient Silk Road connecting China and Central Asia (Dong et al. 2018). Most ancient walled settlements in the Hexi Corridor are dated between Han (202 BC-AD 220) and Qing (AD 1644-1911) Dynasties, which are thousands of years later than those in the Yellow and Yangtze River valleys. The notable exception is the Sanjiao walled settlement in Jinchang, which has been dated between 1110-430 cal BC. Sanjiao is generally considered as "the earliest walled settlement" in the Hexi Corridor (Pu and Pang 1990; Li 1997).

Nevertheless, there is uncertainty around the dated age of Sanjiao. So far, only two charcoal samples from the cultural units at Sanjiao have been collected for dating, with the liquid scintillation counting (LSC) dating method employed (IACASS 1981; Table 1). Although those samples give the approximate time range from the foundation to abandonment or destruction of Sanjiao, they may not be sufficient to determine the precise age of the initial construction of the site (Shao 2012). Also, the age of the walls rather than that of potentially later contexts within those walls (i.e., cultural units) could give a more accurate estimate about the age of the settlement. Hence, there is a need to reassess the chronology of Sanjiao (Schiffer 1986; Dong et al. 2014). Furthermore, other issues pertinent to Sanjiao such as how the inhabitants of Sanjiao adapted to local environmental conditions and why Sanjiao was built remain unexplored. Resolving the above issues is vital in supplementing the history of the Hexi Corridor and tracking the historical development of the ancient Silk Road. In this study, we employ accelerator mass spectrometry radiocarbon (AMS ${ }^{14} \mathrm{C}$ ) dating to remeasure samples from Sanjiao and reassess its chronology. Also, we explore the subsistence strategies of the site inhabitants according to the identification of charred plant seeds and charcoal. Finally, the purpose of building Sanjiao itself is explored.

\section{STUDY AREA}

Sanjiao is located near the modern city of Jinchang, in the east-central section of the Hexi Corridor, surrounded by the Qilian Mountains and Badain Jaran Desert (Figure 1). The altitude of Jinchang decreases gradually from the southwest to the northeast, with a mean altitude of $1500 \mathrm{~m}$ asl. The climate in the region is arid and windy, with a mean annual temperature of $9.5^{\circ} \mathrm{C}$ and mean annual precipitation of $122.3 \mathrm{~mm}$ (Huang et al. 2018). The Dongda and Xida Rivers flow from the Qilan Mountains through this region.

Sanjiao was first discovered and excavated in the 1980s. Pu and Pang (1990) considered Sanjiao to be an ancient city. However, in comparison to other ancient settlements in central China, Sanjiao appears to have been less developed and somewhat smaller, which is better to be considered as a walled settlement. Sanjiao is oriented toward the south, with an irregular triangle-shape. The site measures $154 \mathrm{~m}$ from north to south and $132 \mathrm{~m}$ from east to west. The walls of Sanjiao are made of piled earth and are 6-8 m thick at their base (Figure 2).

Sanjiao is classified as part of the Late Bronze Age Shajing Culture (1000-400 BC) based on the unique ceramics unearthed there $(\mathrm{Pu}$ and Pang 1990). This places the site later than the 
Table 1 Radiocarbon dates from Sanjiao.

\begin{tabular}{|c|c|c|c|c|c|c|c|}
\hline \multirow[b]{2}{*}{ Lab no. } & \multirow{2}{*}{$\begin{array}{l}\text { Dating } \\
\text { method }\end{array}$} & \multirow{2}{*}{$\begin{array}{l}\text { Dated } \\
\text { material }\end{array}$} & \multirow{2}{*}{$\begin{array}{l}{ }^{14} \mathrm{C} \text { age } \\
(\mathrm{BP})\end{array}$} & \multicolumn{2}{|c|}{ Calibrated age (cal yr BC) } & \multirow[b]{2}{*}{ Site } & \multirow[b]{2}{*}{ Reference } \\
\hline & & & & $(68.2 \%)$ & $(95.4 \%)$ & & \\
\hline BK-79062 & LSC & $\begin{array}{l}\text { Deadwood } \\
\text { (species } \\
\text { unknown) }\end{array}$ & $2730 \pm 95$ & $980 \mathrm{BC}(68.2 \%) 804 \mathrm{BC}$ & $\begin{array}{l}\text { 1206BC }(0.1 \%) 1202 \mathrm{BC} \\
1196 \mathrm{BC}(2.0 \%) 1140 \mathrm{BC} \\
1134 \mathrm{BC}(93.1 \%) 758 \mathrm{BC} \\
678 \mathrm{BC}(0.2 \%) 672 \mathrm{BC}\end{array}$ & Hamodun & Xie 2002 \\
\hline BK-79063 & LSC & $\begin{array}{l}\text { Deadwood } \\
\text { (species } \\
\text { unknown) }\end{array}$ & $2680 \pm 125$ & $\begin{array}{l}1024 \mathrm{BC}(62.9 \%) 751 \mathrm{BC} \\
682 \mathrm{BC}(1.7 \%) 668 \mathrm{BC} \\
636 \mathrm{BC}(1.1 \%) 626 \mathrm{BC} \\
614 \mathrm{BC}(2.6 \%) 592 \mathrm{BC}\end{array}$ & $\begin{array}{l}1192(0.7 \%) 1173 \mathrm{BC} \\
1164(0.8 \%) 1144 \mathrm{BC} \\
1131(93.2 \%) 476 \mathrm{BC} \\
462 \mathrm{BC}(0.2 \%) 456 \mathrm{BC} \\
444 \mathrm{BC}(0.5 \%) 431 \mathrm{BC}\end{array}$ & Hamodun & Xie 2002 \\
\hline BK-79064 & LSC & $\begin{array}{l}\text { Deadwood } \\
\text { (species } \\
\text { unknown) }\end{array}$ & $2570 \pm 100$ & $\begin{array}{l}826 \mathrm{BC}(27.1 \%) 726 \mathrm{BC} \\
720 \mathrm{BC}(3.0 \%) 704 \mathrm{BC} \\
695 \mathrm{BC}(38.0 \%) 540 \mathrm{BC}\end{array}$ & $898 \mathrm{BC}(95.4 \%) 412 \mathrm{BC}$ & Hamodun & Xie 2002 \\
\hline ZK-0789 & LSC & $\begin{array}{l}\text { Deadwood } \\
\text { (species } \\
\text { unknown) }\end{array}$ & $2540 \pm 80$ & $\begin{array}{l}802 \mathrm{BC}(23.6 \%) 728 \mathrm{BC} \\
693 \mathrm{BC}(44.6 \%) 542 \mathrm{BC}\end{array}$ & $815 \mathrm{BC}(95.4 \%) 414 \mathrm{BC}$ & Hamodun & Xie 2002 \\
\hline ZK-0739 & LSC & Charcoal & $2675 \pm 100$ & $978 \mathrm{BC}(68.2 \%) 770 \mathrm{BC}$ & 1110BC $(95.4 \%) 540 \mathrm{BC}$ & Sanjiao & $\begin{array}{l}\text { IACASS } \\
1981\end{array}$ \\
\hline BK-79030 & LSC & Charcoal & $2600 \pm 90$ & $\begin{array}{l}892 \mathrm{BC}(2.7 \%) 878 \mathrm{BC} \\
846 \mathrm{BC}(36.1 \%) 736 \mathrm{BC} \\
688 \mathrm{BC}(6.2 \%) 663 \mathrm{BC} \\
647 \mathrm{BC}(23.3 \%) 548 \mathrm{BC}\end{array}$ & $924 \mathrm{BC}(95.2 \%) 430 \mathrm{BC}$ & Sanjiao & $\begin{array}{l}\text { IACASS } \\
1981\end{array}$ \\
\hline LZU-14218 & AMS & Barley & $2230 \pm 20$ & $\begin{array}{l}364 \mathrm{BC}(9.0 \%) 352 \mathrm{BC} \\
295 \mathrm{BC}(54.5 \%) 229 \mathrm{BC} \\
220 \mathrm{BC}(4.7 \%) 212 \mathrm{BC}\end{array}$ & $\begin{array}{l}380 \mathrm{BC}(17.1 \%) 346 \mathrm{BC} \\
321 \mathrm{BC}(78.3 \%) 206 \mathrm{BC}\end{array}$ & Sanjiao & This study \\
\hline LZU-14219 & AMS & Barley & $2165 \pm 25$ & $\begin{array}{l}350 \mathrm{BC}(38 \%) 304 \mathrm{BC} \\
210 \mathrm{BC}(30.2 \%) 173 \mathrm{BC}\end{array}$ & $\begin{array}{l}358 \mathrm{BC}(47.5 \%) 278 \mathrm{BC} \\
259 \mathrm{BC}(2.0 \%) 242 \mathrm{BC} \\
236 \mathrm{BC}(43.5 \%) 156 \mathrm{BC} \\
134 \mathrm{BC}(2.5 \%) 116 \mathrm{BC}\end{array}$ & Sanjiao & This study \\
\hline
\end{tabular}


Table 1 (Continued)

\begin{tabular}{|c|c|c|c|c|c|c|c|}
\hline \multirow[b]{2}{*}{ Lab no. } & \multirow{2}{*}{$\begin{array}{l}\text { Dating } \\
\text { method }\end{array}$} & \multirow{2}{*}{$\begin{array}{l}\text { Dated } \\
\text { material }\end{array}$} & \multirow{2}{*}{$\begin{array}{l}{ }^{14} \mathrm{C} \text { age } \\
(\mathrm{BP})\end{array}$} & \multicolumn{2}{|c|}{ Calibrated age (cal yr BC) } & \multirow[b]{2}{*}{ Site } & \multirow[b]{2}{*}{ Reference } \\
\hline & & & & $(68.2 \%)$ & $(95.4 \%)$ & & \\
\hline LZU-14221 & AMS & Barley & $2230 \pm 30$ & $\begin{array}{l}366 \mathrm{BC}(10.1 \%) \\
300 \mathrm{BC}(58.1 \%) \\
3510 \mathrm{BC}\end{array}$ & $\begin{array}{l}384 \mathrm{BC}(20.8 \%) 339 \mathrm{BC} \\
328 \mathrm{BC}(74.6 \%) \\
204 \mathrm{BC}\end{array}$ & Sanjiao & This study \\
\hline LZU-17056 & AMS & Charcoal & $2540 \pm 25$ & $\begin{array}{l}794 \mathrm{BC}(47.6 \%) 752 \mathrm{BC} \\
682 \mathrm{BC}(9.3 \%) 668 \mathrm{BC} \\
621 \mathrm{BC}(11.3 \%) 592 \mathrm{BC}\end{array}$ & $\begin{array}{l}798 \mathrm{BC}(50.3 \%) 744 \mathrm{BC} \\
686 \mathrm{BC}(11.3 \%) 665 \mathrm{BC} \\
644 \mathrm{BC}(33.8 \%) \\
551 \mathrm{BC}\end{array}$ & Sanjiao & This study \\
\hline LZU-17057 & AMS & Charcoal & $2580 \pm 25$ & $800 \mathrm{BC}(68.2 \%) 776 \mathrm{BC}$ & $\begin{array}{l}810 \mathrm{BC}(93.9 \%) 756 \mathrm{BC} \\
679 \mathrm{BC}(1.0 \%) 672 \mathrm{BC} \\
603 \mathrm{BC}(0.5 \%) 598 \mathrm{BC}\end{array}$ & Sanjiao & This study \\
\hline LZU-17059 & AMS & Charcoal & $2650 \pm 25$ & $821 \mathrm{BC}(68.2 \%) 800 \mathrm{BC}$ & $\begin{array}{l}\text { 888BC }(1.1 \%) 882 \mathrm{BC} \\
842 \mathrm{BC}(94.3 \%) 792 \mathrm{BC}\end{array}$ & Sanjiao & This study \\
\hline
\end{tabular}




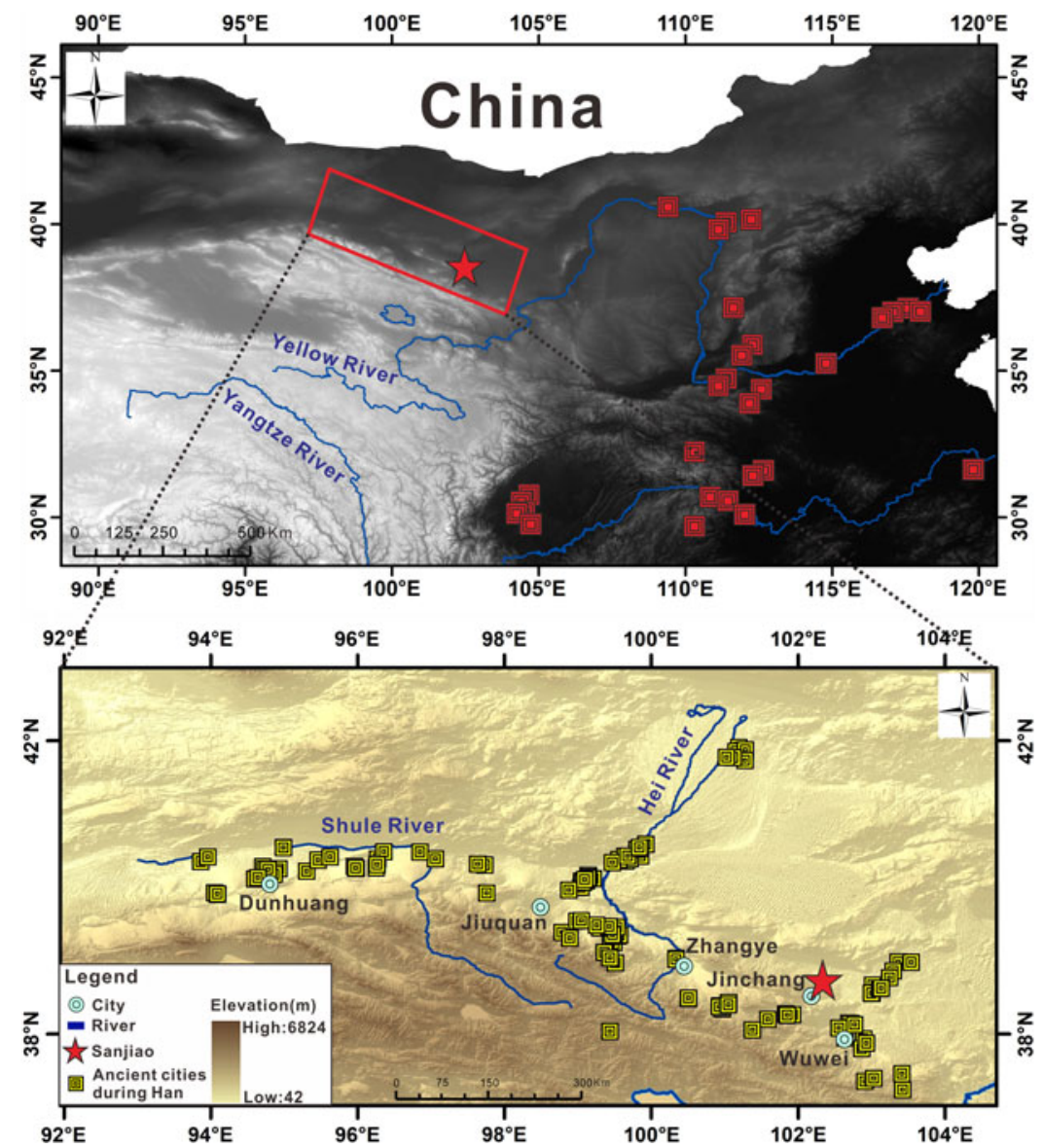

Figure 1 The distribution of ancient walled settlements in China and the Hexi Corridor: yellow squares represent the walled settlements built in the Han Dynasty; red squares represent the walled settlements built before the Han Dynasty; the star represents the Sanjiao walled settlement. (Please see electronic version for color figures.)

Machang type of the Majiayao Culture (2300-2000 BC), Qijia Culture (2300-1500 BC), and Siba Culture (1900-1400 BC) in the Hexi Corridor.

\section{MATERIALS AND METHODS}

Fieldwork was conducted at Sanjiao in 2014 and 2017. During the 2014 fieldwork, we collected 10 soil samples from different cultural contexts inside the Sanjiao walled settlement. Three were obtained from ash pits and seven were derived from different cultural layers as shown in Figure 2A. During the 2017 fieldwork, we collected three soil samples from the base of the walls in the northwestern part of Sanjiao. One of them was taken from the surface of the wall (Figure 2D), and two of them were taken inside the wall (Figure 2C). All of the soil samples were processed by the flotation method. The soil was washed over in a bucket with a \#80 mesh sieve (aperture size of $0.2 \mathrm{~mm}$ ) to gather any carbonized remains. The carbonized remains were dried in the shade and then sorted. Charred plant seeds were 


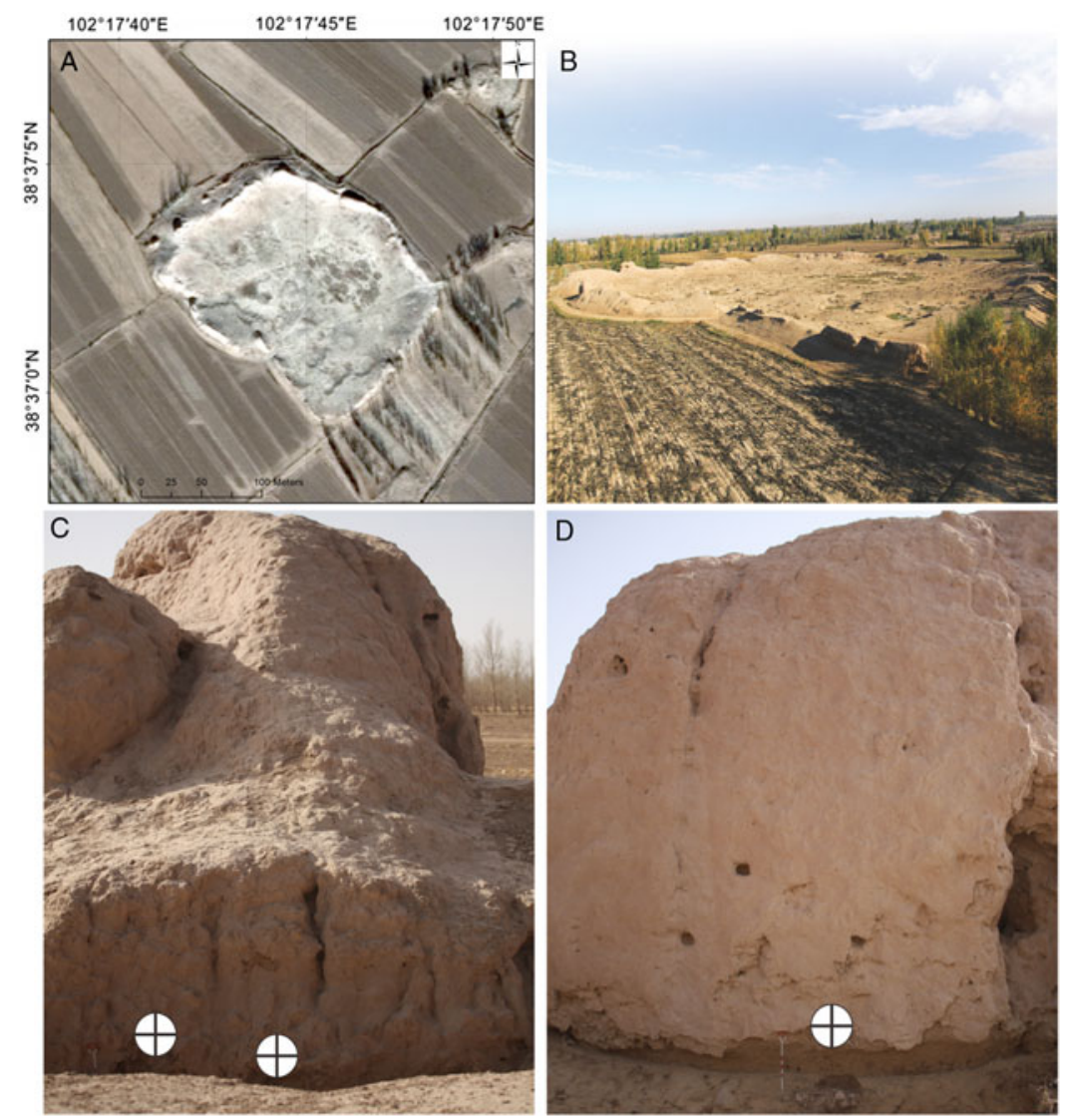

Figure 2 Remote-sensing image and photographs of Sanjiao: remote-sensing image of Sanjiao; (B) photograph of the whole Sanjiao walled settlement; (C) and (D) the walls of Sanjiao from which the charcoal samples are collected (white dots).

identified by Professor Jingang Yang at the Paleoethnobotany Laboratory, Institute of Archaeology, Chinese Academy of Social Science. Charcoal was identified according to its cellular structure under a reflected light microscope in the MOE Key Laboratory of Western China's Environmental Systems at the Lanzhou University.

Charcoal from the walls as well as charred barley seeds from three different contexts (including an ash pit and two cultural layers) were dated. The two types of material were dated to cross check and validate the resulting ages. All samples were prepared with the standard pretreatment (acid-alkali-acid) in the MOE Key Laboratory of Western China's Environmental Systems at the Lanzhou University. The carbonated samples were treated in $2 \mathrm{~mol} / \mathrm{L}$ hydrochloric acid $(\mathrm{HCl})$ at $60^{\circ} \mathrm{C}$. The $\mathrm{HCl}$ solution was refreshed every two hours until no effervescence was observed. Then, samples were rinsed with distilled water, soaked in $0.5 \mathrm{~mol} / \mathrm{L} \mathrm{NaOH}$ at $60^{\circ} \mathrm{C}$. The $\mathrm{NaOH}$ solution was also refreshed every two hours until the liquid became clear. Third, those samples were treated under $1 \mathrm{~mol} / \mathrm{L}$ hydrochloric acid $(\mathrm{HCl})$ at $60^{\circ} \mathrm{C}$ for $2 \mathrm{hr}$ and rinsed again with distilled water. Lastly, the samples were dried for $48 \mathrm{hr}$ for AMS ${ }^{14} \mathrm{C}$ dating performed at Peking University. Ages were calibrated using the OxCal v4.3.2 online program (Bronk and Lee 2013) and the IntCal13 calibration curve 


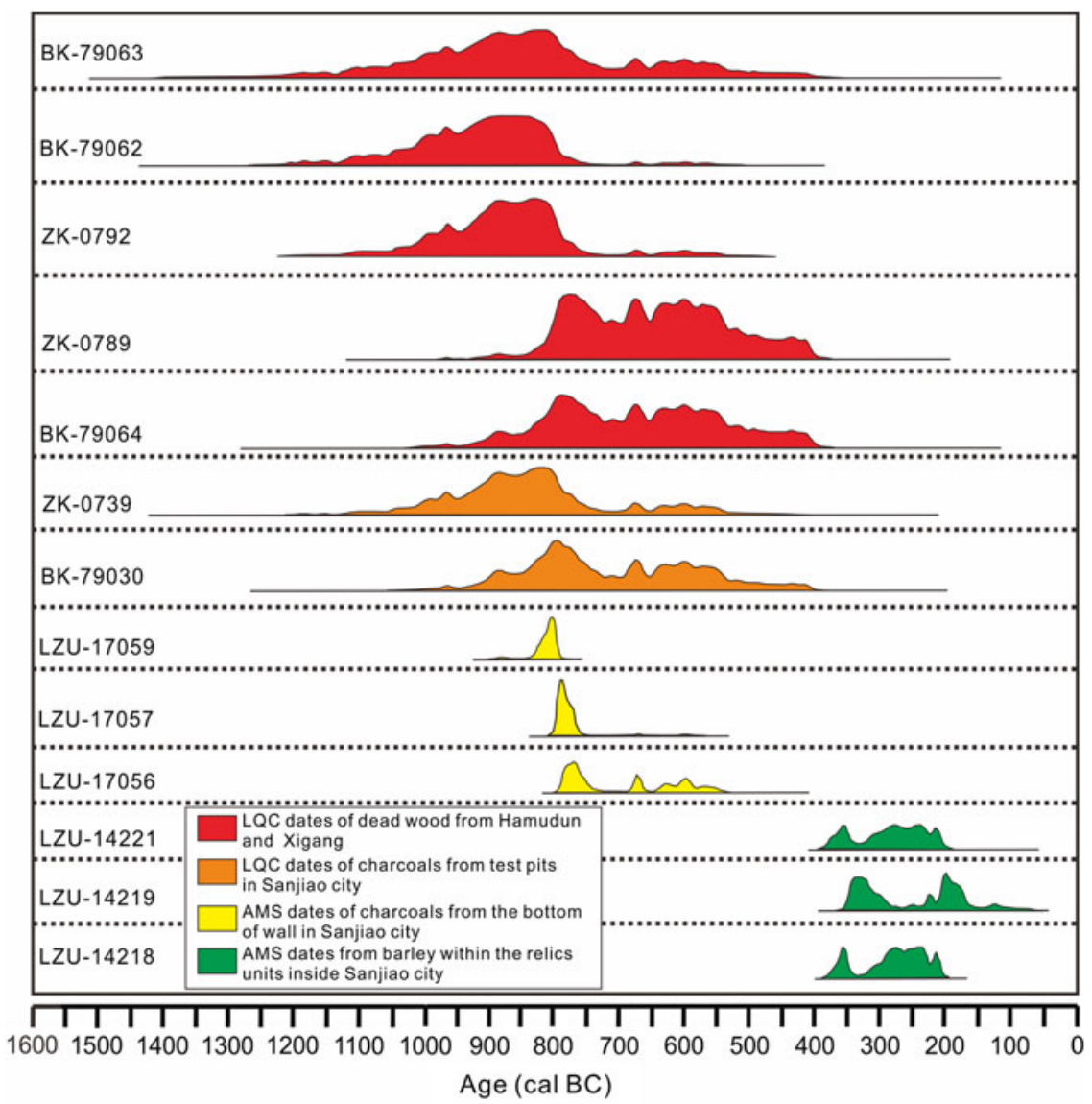

Figure 3 The comparison of the probability of ${ }^{14} \mathrm{C}$ dates from Sanjiao and the tombs nearby: the red ones represent the LSC dates of dead wood from Hamudun and Xigang tombs by Xie (2002); the orange ones refer to the LSC dates of charcoal from test pit in Sanjiao by Xie (2002); the yellow ones are the AMS dates of charcoal from the walls in Sanjiao (this study); the green ones are the AMS dates of barley from the Shajing cultural layers inside Sanjiao (this study).

(Reimer et al. 2013). Also, phase modeling in the OxCal v4.3.2 program was employed to give a more robust estimate of Sanjiao's initial construction date. All ages are reported as "cal. AD/BC."

\section{RESULTS}

Archaeologically, the ages the walls of Sanjiao could give a better chronology of Sanjiao's initial construction date. The three AMS ${ }^{14} \mathrm{C}$ ages derived from the charcoal from the walls are relatively close and fall into the period 888-551 cal BC (Figure 3; Table 1), which coincides with the Western Zhou (1046-771 BC) and spring and autumn periods (770-476 BC). The result of the phase modeling further shows that the walls of Sanjiao were built in the period 855-797 cal BC, with the median age of $828 \pm 92$ cal BC (Figure 4). The ${ }^{14} \mathrm{C}$ dates from the contexts inside Sanjiao more likely reflect the length of occupation. For the three AMS ${ }^{14} \mathrm{C}$ dates derived from charred barley seeds in the Shajing contexts within 


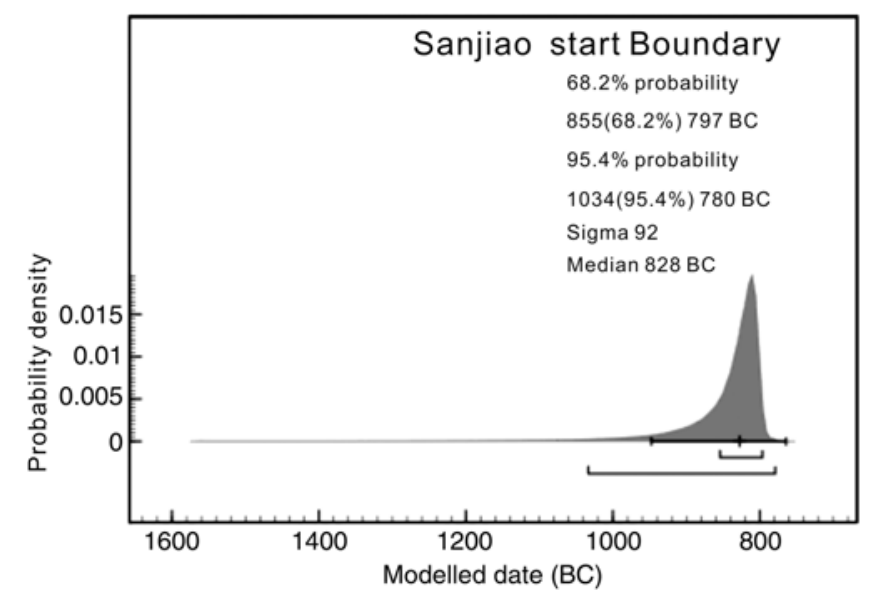

Figure 4 The modeled age ranges of Sanjiao's walls and their median: the start boundary of wall construction is shown with $68.2 \%$ and $95.4 \%$ probability range.

Sanjiao, one in the ash pit is dated 380-206 cal BC. The two others in cultural contexts are dated at 358-116 and 384-204 cal BC, respectively (Figure 3; Table 1). Our AMS dates from the charred barley seeds fall between the mid-late Warring States Period (475-221 BC) and early Qin-Han Dynasties (221 BC-AD 9), indicating Sanjiao was inhabited during the mid-late Warring States and early Qin-Han Dynasties in China.

Through the flotation of soil samples from different contexts inside Sanjiao, 469 charred plant seeds of 17 taxa were identified (Figure 5; Table 2). Among these charred seeds, the crop seeds including broomcorn millet, barley, and foxtail millet are found in the largest proportion (Figure 5; Table 2). Charred grass seeds of 14 taxa were identified, including Squarrose Agriophyllum (Agriophyllum squarrosum (L.) Moq.), Lambsquarters (Chenopodium album L.), Common Russian Thistle (Salsola collina Pall.), Salsola ruthenica (Salsola ruthenica lljin), Green Bristlegrass (Setaria viridis (L.) Beauv.), Barnyardgrass (Echinochloa crus galli (L.) Beauv.), Garden Sorrel (Rumex acetosa Linn.), Dockleaved Knotweed (Polygonum lapathifolium L.), Sphaerophysa salsula, Alhagi sparsifolia, Nitraria sibirica Pall., Chinese Iris (Iris lacteal pall. var. chinensis Koidz), Vittaria flexuosa, and Carolina Geranium (Geranium carolinanum L.) (Figure 5; Table 2). Additionally, a total of 894 pieces of charcoal of seven taxa were identified, including Tamarix chinensis, Tamarix (Tamarix L.), willow (Salix L.), spruce (Picea), sea buckthorn (Hippophae), Poaceae, and birch (Betulaceae L.) (Figure 6; Table 3).

\section{DISCUSSION}

\section{Sanjiao is the Earliest Walled Settlement in the Hexi Corridor}

Previous studies, which were based on conventional ${ }^{14} \mathrm{C}$ dates from Sanjiao and the nearby Hamodun and Xigang tombs, stated that Sanjiao was built during the Shajing Period (1000-400 BC; Table 1; Pu and Pang 1990; Xie 2002). Yet, those ${ }^{14} \mathrm{C}$ dates may be inaccurate due to the "old wood effect" (Dean 1978; Schiffer 1986; Dong et al. 2014). The ${ }^{14} \mathrm{C}$ dates obtained from charcoal or dead woods unearthed from archaeological sites may 


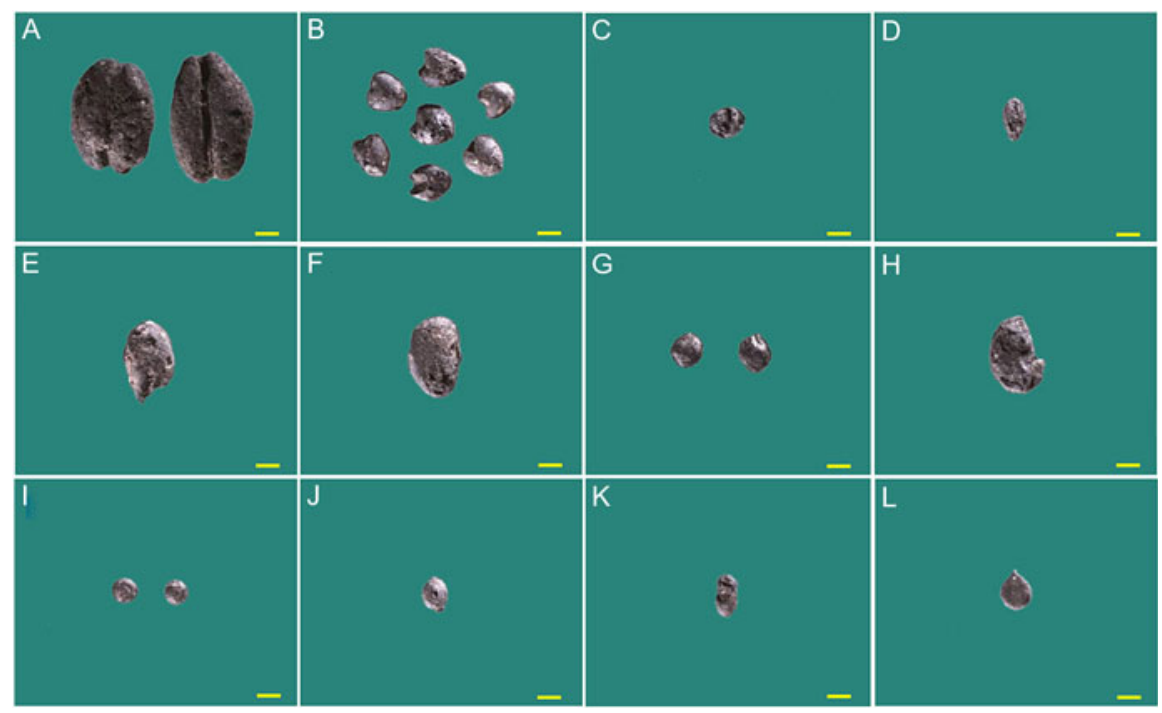

Figure 5 Charred seed remains from Sanjiao: (A) Hordeum vulgare; (B) Panicum miliaceum; (C) Setaria italica; (D) Setaria viridis (L.)Beauv.; (E) Nitraria sibirica Pall.; (F) Iris lacteal pall. var.; (G) Agriophyllum squarrosum (L.)Moq.; (H) Sphaerophysa salsula; (I) Salsola collina Pall. (J) Echinochloa crus galli (L.)Beauv.; (K) Geranium carolinanum L.; (L) Polygonum lapathifolium L.

be much older than the actual age of those sites, as the dated material could have originated from long-lived trees that grew decades or centuries before their utilization by settlers (Dong et al. 2014). Additionally, the dates from Sanjiao were all measured through LSC. Compared to LSC, the advantage of AMS is that only tiny amount of carbon-containing material is required for dating, which decreases the chance of mixing carbon from different sources (Lanting and van der Plicht 2015).

The AMS ${ }^{14} \mathrm{C}$ dates of our charcoal obtained from the walls of Sanjiao match very well. Also, they correspond with the previous $\mathrm{LSC}{ }^{14} \mathrm{C}$ dates of charcoal obtained from the cultural contexts of Sanjiao (Figure 3), suggesting a minimal "old wood effect." Their good match may be related to the absence of old trees or forests around the site. Taking northeastern Tibetan Plateau as an example, the farmers of the Majiayao Culture in the Loess Plateau started to settle in that area during the mid-late Holocene (Chen et al. 2015b), a time when the forest was abundant according to the tree pollen record of the Qinghai Lake (Shen et al. 2005). At different Majiayao sites, there is a considerable disparity of ${ }^{14} \mathrm{C}$ dates between charcoal and charred seeds, even though those materials are obtained from the same cultural contexts. This could be attributable to the utilization of old trees in those sites, subjecting the dating materials to the "old wood effect" (Dong et al. 2014).

The climate became cold and dry during 4200-2800 BP (Mischke and Zhang 2010), and the reduction of tree pollen suggests that forest was gradually replaced by the shrubs and herbs (Shen et al. 2005). This coincides with the establishment of the agro-pastoral economy and the associated expansion of grazing on the northeast Tibetan Plateau (Chen et al. 2015b; Dong et al. 2016b).

Due to continuous cultural exchange across Eurasia during the Bronze Age, in the Hexi Corridor, the subsistence strategies were changed from millet agriculture to the 
Table 2 Taxa of charred plant seeds and their total number and relative frequencies from Sanjiao.

\begin{tabular}{|c|c|c|c|c|c|c|c|c|c|c|c|c|c|}
\hline Taxa & & $\begin{array}{l}\text { Ash } \\
\text { pit } 1\end{array}$ & $\begin{array}{l}\text { Ash } \\
\text { pit } 2\end{array}$ & $\begin{array}{l}\text { Ash } \\
\text { pit } 3\end{array}$ & $\begin{array}{l}\text { Cultural } \\
\text { layer } 1\end{array}$ & $\begin{array}{l}\text { Cultural } \\
\text { layer } 2\end{array}$ & $\begin{array}{l}\text { Cultural } \\
\text { layer } 3\end{array}$ & $\begin{array}{l}\text { Cultural } \\
\text { layer } 4\end{array}$ & $\begin{array}{l}\text { Cultural } \\
\text { layer } 5\end{array}$ & $\begin{array}{l}\text { Cultural } \\
\text { layer } 6\end{array}$ & $\begin{array}{l}\text { Cultural } \\
\text { layer } 7\end{array}$ & $\begin{array}{l}\text { Frequency } \\
(\%)\end{array}$ & $\begin{array}{c}\text { Total } \\
\text { number }\end{array}$ \\
\hline \multirow[t]{3}{*}{$\begin{array}{l}\text { Agriculture } \\
\text { crop }\end{array}$} & $\begin{array}{l}\text { Hordeum } \\
\text { vulgare } L .\end{array}$ & 9 & 21 & 15 & 19 & 22 & 1 & 13 & 38 & 22 & 9 & 100 & 169 \\
\hline & $\begin{array}{l}\text { Panicem } \\
\text { miliaceum }\end{array}$ & 5 & 4 & 23 & 24 & 26 & 4 & 8 & 61 & 7 & 5 & 100 & 168 \\
\hline & Setaria italica & & & & & 2 & & & & & 2 & 20 & 4 \\
\hline \multirow[t]{4}{*}{ Chenopodiaceae } & $\begin{array}{l}\text { Chenopodiaceae } \\
\text { album L. }\end{array}$ & & & & & 1 & & & 3 & & 4 & 30 & 8 \\
\hline & $\begin{array}{l}\text { Salsola collina } \\
\text { Pall }\end{array}$ & & & & & 2 & 13 & & 3 & & 1 & 40 & 19 \\
\hline & Salsola ruthenica & & & 7 & & & & & & & & 10 & 7 \\
\hline & $\begin{array}{l}\text { Agriophyllum } \\
\text { squarrosum }\end{array}$ & & & & & & & & 61 & & & 10 & 61 \\
\hline \multirow[t]{2}{*}{ Poaceae } & Setaria viridis & & & 1 & & & 3 & & 4 & & & 30 & 8 \\
\hline & $\begin{array}{l}\text { Echinochloa } \\
\text { crusgalli }\end{array}$ & & & & & & & 1 & & & & 10 & 1 \\
\hline \multirow[t]{2}{*}{ Polygonaceae } & $\begin{array}{l}\text { Rumex acetosa } \\
\text { Linn. }\end{array}$ & & & & & & & 1 & & & & 10 & 1 \\
\hline & $\begin{array}{l}\text { Polygonum } \\
\text { lapathifolium L. }\end{array}$ & & & & & & & 1 & & & & 10 & 1 \\
\hline \multirow[t]{2}{*}{$\begin{array}{l}\text { Leguminosae } \\
\text { sp. }\end{array}$} & $\begin{array}{l}\text { Sphaerophysa } \\
\text { salsula }\end{array}$ & & & & 5 & & & & & & & 10 & 5 \\
\hline & $\begin{array}{l}\text { Alhagi } \\
\text { sparsifolia Shap }\end{array}$ & & & & & & & 2 & & & & 10 & 2 \\
\hline Zygophyllaceae & $\begin{array}{l}\text { Nitraria } \\
\text { tangutorum Bor }\end{array}$ & & 1 & & 2 & & & & 1 & 1 & & 40 & 5 \\
\hline Iridaceae & $\begin{array}{l}\text { Iris lacteal Pall. } \\
\text { Var. chinensis }\end{array}$ & & 1 & & 2 & & & & & 2 & & 30 & 5 \\
\hline Cyperaceae & Carex tristachya & & & & & & & & 1 & 1 & & 20 & 2 \\
\hline Geraniaceae & $\begin{array}{l}\text { Geranium } \\
\text { sibiricum L. }\end{array}$ & & & & & & & & 1 & & & 10 & 1 \\
\hline
\end{tabular}




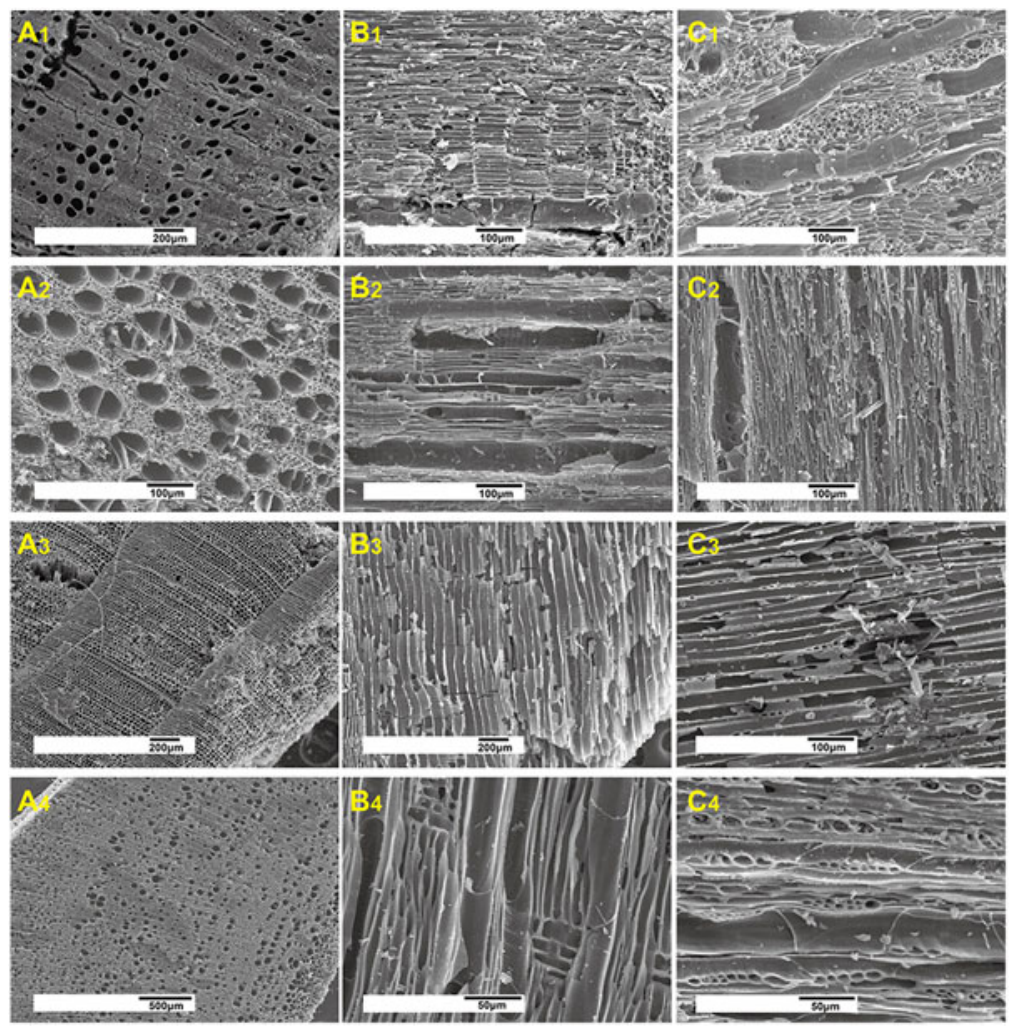

Figure 6 Fossilized charcoals identified in Sanjiao: (A1, B1, and C1) Tamarix L.; (A2, B2, and C2) Salix L.; (A3, B3, and C3) Picea; (A4, B4, and C4) Hippophae. $\mathrm{A}$ is the transverse section of charcoal; $\mathrm{B}$ is the radial section of charcoal; $\mathrm{C}$ is the tangential section of charcoal.

Table 3 Taxa of charcoal and their relative frequencies and abundance ratio from Sanjiao.

\begin{tabular}{|c|c|c|c|c|c|c|}
\hline Taxa & $\begin{array}{c}\text { Ash } \\
\text { pit }\end{array}$ & $\begin{array}{c}\text { Cultural } \\
\text { layer }\end{array}$ & $\begin{array}{c}\text { Absolute fragment } \\
\text { count }\end{array}$ & $\begin{array}{l}\text { Abundance } \\
\text { ratio }(\%)\end{array}$ & Ubiquity & $\begin{array}{c}\text { Frequency } \\
(\%)\end{array}$ \\
\hline $\begin{array}{l}\text { Tamarix } \\
\text { chinensis }\end{array}$ & 3 & 24 & 27 & 3.02 & 4 & 40 \\
\hline Tamarix & 257 & 539 & 796 & 89.04 & 10 & 100 \\
\hline Salix & 9 & 34 & 43 & 4.81 & 9 & 90 \\
\hline Picea & & 14 & 14 & 1.57 & 3 & 30 \\
\hline Hippophae & 2 & 5 & 7 & 0.78 & 3 & 30 \\
\hline Betulaceae & & 1 & 1 & 0.11 & 1 & 10 \\
\hline Poaceae & & 6 & 6 & 0.67 & 1 & 10 \\
\hline
\end{tabular}

combination of agro-pastoral activities and barley agriculture. Bronze-smelting activities also started to take place. This led to deforestation and the desertification in the Hexi Corridor (Li et al. 2011; Zhou et al. 2012), and only drought-tolerant shrubs were found there in the Bronze Age and the historical period (Liu et al. 2018). Also, the agro-pastoral economy 


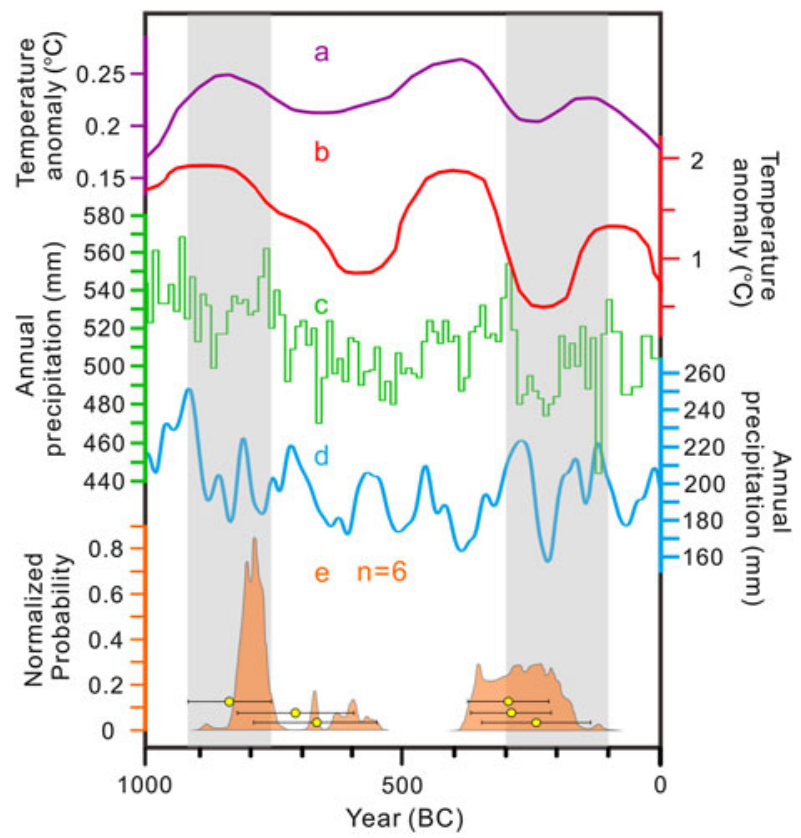

Figure 7 Comparison between the probability of ${ }^{14} \mathrm{C}$ dates from Sanjiao and the paleo-climatic records in the Hexi Corridor and its nearby regions: (a) temperature anomaly of the North Hemisphere $\left(30-90^{\circ} \mathrm{N}\right)$ by Marcott et al. (2013) (purple); (b) $\delta^{18} \mathrm{O}$ temperature anomaly of Agassiz cap on Ellesmere Island by Lecavalier et al. (2017) (red, smoothed with the Gaussian filter $[\sigma=50 \mathrm{y}]$ ); (c) Asia monsoon record of the stalagmite from Dongge Cave by Dykoski et al. (2005); (d) annual precipitation reconstructed from tree-ring in eastern Qilian Mountains by Yang et al. (2014); (e) probability of ${ }^{14} \mathrm{C}$ dates from Sanjiao (orange). The yellow circle represents the dates of Sanjiao obtained in this study. The gray shadow indicates the periods of climate deterioration.

facilitated human mobility and hence, fewer permanent structures were built and fewer trees were consumed. The settlement at Sanjiao was primarily composed of portable yurts ( $\mathrm{Pu}$ and Pang 1990). Those portable yurts together with the piled-earth walls at Sanjiao may further evidence the dominance of the agro-pastoral economy during the time ( $\mathrm{Pu}$ and Pang 1990). Our AMS dates from charcoal and the previous LSC dates support the hypothesis that settlement was built during the Shajing Period (1000-400 BC), as indicated by our phase modeling suggesting that the walls of Sanjiao were built in the period of 855-797 cal BC, with the median age of $828 \pm 92$ cal BC.

Based on the historical records such as Shiji (The Records of the Scribe) and Hanshu (The Book of Han), the Hexi Corridor was conquered and controlled by various nomadic regimes, including Rouzhi,Wusun, and Xiongnu, before it was under the rule of the central government of China during the reign of Emperor Hanwu (141-87 BC). After the victory over Xiongnu, the Han Dynasty government set up four counties in the Hexi Corridor. In addition, several walled settlements were built there when the Silk Road was established. 
According to dozens of ${ }^{14} \mathrm{C}$ dates from multiple ancient cities in eastern Qinghai (Dong et al. 2016a) and archaeological investigation in ancient Juyan Oasis (Hu and Li 2014), there are no walled settlements built earlier than Sanjiao in the Hexi Corridor. Based on these lines of evidence, Sanjiao could be seen as the earliest walled settlement in the Hexi Corridor.

\section{Why Was the Sanjiao Walled Settlement Built?}

Climate-induced shortage of subsistence resource could drive social instability or even conflicts among regions (Lee et al. 2017; Lee 2018). This might eventually induce the need for walled settlements for the protection of settlers (Wu 2002; Qiu and Yao 2003). The construction of walled settlements in northern China is coincident with frequent conflicts in the region (Qian 2000; Qiu and Yao 2003). It is worth noting that the period of widespread construction of walled settlements in China corresponds with a cold and dry climate in East Asia (Cao 1996; Ma 1998; Qian 2000; Marcott et al. 2013; Chen et al. 2015a), suggesting climate change to be an essential factor in facilitating the construction of walled settlements. A cold and dry climate lasting for decades or centuries might lead to the shrinkage of agricultural production, causing frequent conflict among different tribes/states and even the transformation and alternation of ancient cultures (Dong et al. 2017b). Such a phenomenon is found all over the world, for example, the collapse of the Akkadian Empire in Mesopotamia (2334-2154 BC; Weiss et al. 1993), the de-urbanization of Harappa Culture in Indus Valley (2600-1500 BC; Staubwasser et al. 2003), and the decline of Maya Culture in Mesoamerica (AD 400-900; Haug et al. 2003; Medina-Elizalde and Rohling 2012).

The Hexi Corridor, located at the margin of the monsoon region, is a transitional zone between farming and pastoral activities. The climate there is much more arid than that in the east of China. This makes local precipitation and water availability critically important to people's livelihoods and societal development in the Hexi Corridor. Increasing aridity during 4000$3500 \mathrm{BP}$ is often emphasized as one of the proximate causes of socio-political chaos in this area (Zhou et al. 2012). To prove whether the construction of Sanjiao was related to climate deterioration, we compared the ${ }^{14} \mathrm{C}$ dates from Sanjiao with various high-resolution paleo-climatic records in the Hexi Corridor and the nearby regions (Figure 7). Those paleoclimatic records indicate that the temperature and the precipitation dropped drastically at the beginning of the first millennium $\mathrm{BC}$, and the change is a macro-regional one (Figure 7) (Dykoski et al. 2005; Yang et al. 2014; Marcott et al. 2013; Lecavalier et al. 2017), potentially leading to social upheaval and conflict, and consequently the emergence of settlement fortification ( $\mathrm{Li}$ 1995). Given the coincidence between the ${ }^{14} \mathrm{C}$ dates of Sanjiao and the aforementioned climate deterioration (Figure 7), the construction of Sanjiao walled settlement might be a typical example of the settlement fortification driven by climate change. Similar examples can be found in the Mediterranean in the same period (Drake 2012).

\section{What Was the Livelihood in Sanjiao City?}

Archaeobotanical studies shed light on human plant-utilization strategies across time (Lee et al. 2007; Hunt et al. 2008; Jin et al. 2011; Yang et al. 2012; Zhang et al. 2012; Chen et al. 2015b; Long et al. 2017). According to archaeological and archaeobotanical studies, human settlements appeared in the Hexi Corridor in the Majiayao Period (3300-2000 BC) (Xie et al. 2002; Dong et al. 2018). Ancient agriculture relied on foxtail millet and broomcorn millet (Zhou et al. 2016), plants first domesticated in northern China around 8000 BC 
(Lu et al. 2009; Zhao 2011; Zhang et al. 2012). Barley and wheat, domesticated in southwestern Asia during the early Holocene (Lev-Yadun 2000), was introduced to the Hexi Corridor around 2000 BC (Dosdon et al. 2013; Dong et al. 2017a). While millet crops were initially the dominant subsistence plants (Ma et al. 2013, 2014, 2016), exotic barley and wheat became essential staples in the western part of the Gansu-Qinghai region after $1700 \mathrm{BC}$ (Flad et al. 2010; Chen et al. 2015b; Zhou et al. 2016).

Since the first millennium BC, the pastoral economy flourished in the Hexi Corridor. Kuz'mina (2008) argued that the development of pastoral subsistence strategies and eastward migration by nomads was caused by a cold and dry climate across the Eurasian steppe during the time. The origins of nomadic culture in East Asia can also be dated back to the first millennium BC, with rapid development in the eastern grasslands in northern China (Di Cosmo 2010). During 600-400 BC, the nomadic culture diffused to northwestern China, including Qinghai, Gansu, and Ningxia (Watson 1971; Di Cosmo 2010). Some studies argue that Shajing Culture has its origins in Rouzhi, a typical nomadic people (Pu and Pang 1990). The sheep and cattle bones unearthed from Sanjiao and the tombs nearby such as Hamodun and Xigang reveal that the pastoral economy was vital to people's livelihoods in Shajing Culture during the Late Bronze Age.

The three AMS ${ }^{14} \mathrm{C}$ dates of carbonized barley seeds from the ash pit and cultural layers in Sanjiao range between 384-116 cal BC, indicate that Sanjiao was still inhabited in the Late Bronze Age (1000-210 BC). Barley and broomcorn millet were the most important local cultivated crops and the ubiquity of these species reached $100 \%$ of the 10 flotation samples (Table 2). Foxtail millet was utilized at Sanjiao, but its ubiquity is only 20\% (Figure 5; Table 2). The presence and ubiquity of barley and broomcorn millet indicates the Shajing Culture at Sanjiao engaged not only in agro-pastoralism but also agricultural production.

Charcoal obtained from archaeological sites is critical for understanding human woodutilization practices in the past (Thiébault 2002; Asouti and Austin 2005; Dufraisse 2006). Charcoal collected from certain cultural relics in archaeological sites could be considered as the proxy of human activities, and its concentration in cultural remains directly reflect the daily practices of people at the time. In general, humans collect wood for firewood, food, medicine, perfume, and building materials (Wang et al. 2016). In the collected floatation samples, we found 894 pieces of charcoal. They originated from seven tree species, including Tamarix chinensis, Tamarix, Salix, Picea, Hippophae, Betulaceae, and Poaceae (Figure 6; Table 3).

Tamarix occurred with the highest frequency, and its ubiquity reached $100 \%$. Tamarix is often considered a shrub or small tree, and it is mainly distributed in ecologically fragile areas, especially in arid zones such as northwestern China. It is one of the constructive/dominant species of desert and wilderness communities with the advantage of long life expectancy, rapid growth, and high tolerance to aridity and saline/alkaline soil (Yin 2002). Tamarix was used by ancient people in the Hexi Corridor at least as long ago as 2000 BC. During the Siba Culture Period (1900-1400 BC), Tamarix was used as both building material and fuel at the Xichengyi site (Wang et al. 2014). At the Huoshiliang site, Tamarix was gathered as fuel for bronze smelting (Sun et al. 2010). At Sanjiao, Tamarix was probably the primary source of fuel due to its local abundance.

Hippophae is a kind of shrub or small tree that grows in alpine shrub environments and stratified alluvial terraces. It is drought-resistant and able to impede wind-drift sands 
(Forest Stewardship Council 1997). Due to its highly nutritious fruit, Hippophae is a vital food and medicine source, and its archaeological presence is significant for revealing the livelihoods of ancient people. At Sanjiao, seven pieces of charcoal were identified as Hippophae, with relatively low ubiquity (30\%). Despite its low quantity and ubiquity, the presence of Hippophae indicates that its fruit was consumed, and its wood was used as firewood by the inhabitants at Sanjiao. At the Xichengyi site, Hippophae was collected for food (Wang et al. 2014).

Tamarix chinensis, Salix, Picea, Betulaceae, and Poaceae comprise only a tiny portion of our collected charcoals. Salix has a high ubiquity, though its absolute count is small. Salix favors moisture and often grows in stratified alluvial terraces. Because of its ecological adaptability, it is widely distributed (Forest Stewardship Council 1997). Picea, which favors a cold and humid environment, is often found on mountain slopes in northwestern China, and together with Betulaceae, forms the theropencedrymion (Forest Stewardship Council 1997). Our charcoal identification results suggest that these five wood species were seldom utilized by the settlers at Sanjiao. Their remains could probably come from the broad-leaf and coniferous forests that were sporadically distributed around the settlement during the time, with locally available Tamarix as the dominant utilized species.

Briefly, most of the archaeo-botanical crop and wood remains found in Sanjiao are cold-dry resistant species, which corresponds to the climate deterioration in East Asia since $1600 \mathrm{BC}$ (Dykoski et al. 2005; Marcott et al. 2013; Chen et al. 2015a). Barley is highly resistant to low temperature, while broomcorn millet has a stronger adaptive capacity to dry environments relative to foxtail millet (Zhang 1986; Guedes et al. 2015). Many barley and broomcorn millet remains were also found at the Nuomuhong site in the Qaidam Basin where the climate is dry and cold (Dong et al. 2016b). The tree species utilized by the settlers at Sanjiao, such as Tamarix and Hippophae, are also cold-dry resistant. As revealed by the subsistence strategy at Sanjiao, the inhabitants of the settlement might have adapted to the harsh environment in the Hexi Corridor by utilizing cold-dry resistant plant species.

\section{CONCLUSION}

Sanjiao is affirmed by AMS ${ }^{14} \mathrm{C}$ dates as the first walled settlement in the Hexi Corridor. It was built around $828 \pm 92 \mathrm{cal} \mathrm{BC}$. The settlement was probably constructed for defense purposes in relation to the geopolitics in the Hexi Corridor during the late West Zhou and spring-autumn periods. It was still inhabited in 384-116 cal BC. During that time, people relied on barley, broomcorn millet, and auxiliary foxtail millet for food and utilized trees such as Tamarix and Hippophae as fuel. These species are cold-dry resistant, suggesting that people adapted their subsistence strategy to the harsh environment in the Hexi Corridor. Subsequent construction of other ancient settlements around Sanjiao might have facilitated the early development of the Silk Road.

\section{ACKNOWLEDGMENTS}

This research was supported by the National key R\&D Program of China (Grant 2018YFA0606402), Strategic Priority Research Program of the Chinese Academy of Sciences, Pan-Third Pole Environment Study for a Green Silk Road (Plan-TPE) (Grant Nos. XDA2004010101), the National Natural Science Foundation of China (Grant Nos. 41620104007; 41825001), Research Grants Council of The Government of the Hong Kong Special Administrative Region of the People's Republic of China (17610715), and the 
Improvement on Competitiveness in Hiring New Faculties Funding Scheme (4930900) of the Chinese University of Hong Kong. We thank Professor Zhijun Zhao and Mr. Jingang Yang from the Paleoethnobotany Laboratory, Institute of Archaeology, CASS, for identifying crop seeds.

\section{REFERENCES}

Asouti E, Austin P. 2015. Reconstructing woodland vegetation and its exploitation by past societies, based on the analysis and interpretation of archaeological wood charcoal macro-fossils. Environmental Archaeology 10:1-18.

Bronk RC, Lee S. 2013. Recent and planned developments of the program OxCal. Radiocarbon 55:720-730.

Cao BW. 1996. The review of ancient cities in China. Cultural Relics of Central China 3:37-46. In Chinese

Chen FH, Dong GH, Zhang DJ, Liu XY, Jia X, An CB, Ma MM, Xie YW, Barton L, Ren XY, Zhao $\mathrm{ZJ}$, Wu XH, Jones MK. 2015b. Agriculture facilitated permanent human occupation of the Tibetan Plateau after 3600 BP. Science 347: 248-250.

Chen FH, Xu QH, Chen JH, Birks HJB, Liu JB, Zhang SR, Jin LY, An CB, Telford RJ, Cao XY, Wang ZL, Zhang XJ, Selvaraj K, Lu HY, Li YC, Zheng Z, Wang HP, Zhou AF, Dong GH, Zhang JW, Huang XZ, Bloemendal J, Rao ZG. 2015a. East Asian summer monsoon precipitation variability since the last deglaciation. Scientific Reports 5:11186

Dean JS. 1978. Independent dating in archaeological analysis. Advances in archaeological method and theory $1: 223-255$.

Di Cosmo N. 2010. Ancient China and its enemies: the rise of nomadic power in East Asian History. Beijing: China Social Sciences Press. p. 117-156.

Dong GH, Liu FW, Chen FH. 2017b. Environmental and technological effects on ancient social evolution at different spatial scales. Science China Earth Sciences doi:10.1007/s11430-017-9118-3.

Dong GH, Yang YS, Liu XY, Li HM, Cui YF, Wang H, Chen GK, Dodson J, Chen FH. 2018. Prehistoric trans-continental cultural exchange in the Hexi Corridor, northwest China. The Holocene 621-628.

Dong GH, Liu HG, Yang YS, Yang Y, Zhou AF, Wang ZL, Ren XY, Chen FH. 2016a. Emergence of ancient cities in relation to geopolitical circumstances and climates change during late Holocene in northeastern Tibetan Plateau, China. Frontiers of Earth Science 669-682.

Dong GH, Ren LL, Jia X, Liu XY, Dong SM, Li HM, Wang ZX, Xiao YM, Chen FH. 2016b. Chronology and subsistence strategy of
Nuomuhong culture in the Tibetan Plateau. Quaternary International 426:42-49.

Dong GH, Wang ZL, Ren LL, Matuzeviciute GM, Wang H, Ren XY, Chen FH. 2014. A comparative study of ${ }^{14} \mathrm{C}$ dating on charcoal and charred seeds from late Neolithic and Bronze age sites in Gansu and Qinghai province, NW China. Radiocarbon 56:157-163.

Dong GH, Yang YS, Han JY, Wang H, Chen FH. 2017a. Exploring the history of cultural exchange in prehistoric Eurasia from the perspectives of crop diffusion and consumption. Science China Earth Sciences 60:1110-1123.

Dosdon JR, Li X, Zhou X, Zhao K, Sun N, Atahan P. 2013. Origin and spread of wheat in China. Quaternary Science Reviews 72:108-111.

Dufraisse A. 2006. Charcoal anatomy potential, wood diameter and radial growth. BAR International Series 1483:47.

Drake BL. 2012. The influence of climatic change on the Late Bronze Age collapse and the Greek dark ages. Journal of Archaeological Sciences 39: 1862-1870.

Dykoski CA, Edwards RL, Cheng H, Yuan DX, Cai YJ, Zhang ML, Lin YS, Qing JM, An ZS, Revenaugh J. 2005. A high-resolution, absolutedated Holocene and deglacial Asian monsoon record from Dongge Cave, China. Earth and Planetary Science Letters 233(1):71-86.

Flad R, Li SC, Wu XH, Zhao ZJ. 2010. Early wheat in China: results from new studies at Donghuishan in the Hexi corridor. The Holocene 20:955-965.

Forest Stewardship Council. 1997. Chinese forest. Beijing: China Forestry Publishing House. p. 519-534. In Chinese.

Gates C. 2011. Ancient cities: the archaeology of urban life in the ancient Near East and Egypt, Greece and Rome. Taylor and Francis. p. $1-503$

Guedes JADA, Lu HL, Henin AM, Schmidt AH. 2015. Early evidence for the use of wheat and barley as staple crops on the margins of the Tibetan Plateau. Proceedings of the National Academy of Sciences of the United States of America 112:5625-5630.

Huang JW, Han LL, Liu TJ. 2018. Analysis on climate characteristics and meteorological disaster risk in Jinchang city. Journal of Anhui Agriculture Science 46:163-165 
Haug GH, Günther D, Peterson LC, Sigman DM, Hughen KA, Aeschlimann B. 2003. Climate and the collapse of Maya civilization. Science 299:1731-1735.

Hosner D, Wagner M, Tarasov PE, Chen XC, Leipe C. 2016. Spatiotemporal distribution patterns of archaeological sites in China during the Neolithic and Bronze Age: an overview. The Holocene 26:1576-1593.

Hu NK, Li X. 2014. Spatial distribution of an ancient agricultural oasis in Juyan, northwestern China. Frontiers of Earth Science 8:338-350.

Hunt HV, Linden MV, Liu XY, Matuzeviciute GM, Colledge S, Jones MK. 2008. Millets across Eurasia: Chronology and context of early records of the genera Panicum and Setaria from archaeological sites in the Old World. Vegetation History and Archaeobotany 17:5-18.

Institute of Archaeology, Chinese Academy of Social Sciences. 1981. Radiocarbon dating report (8th). Archaeology 366. In Chinese

Jin GY, Zheng TX, Liu CJ, Wang CM, Gao MK. 2011. An important military city of the early western Zhou Dynasty: archaeobotanical evidence from the Chenzhuang site, Gaoqing, Shandong Province. Chinese Science Bulletin 57: 253-260.

Kuz'mina EE. 2008. The prehistory of the Silk Road. Philadelphia: University of Pennsylvania Press. p. 39-08.

Lanting JN, van der Plicht J. 2015. ${ }^{14}$ C-AMS: pros and cons for archaeology. Palaeohistoria:1-12.

Lecavalier BS, Fisher DA, Milne GA, Vinther, BM, Tarasov L, Huybrechts P, Lacelle D, Main B, Zheng J, Bourgeois J, Dyke AS. 2017. High Arctic Holocene temperature record from the Agassiz ice cap and Greenland ice sheet evolution. Proceedings of the National Academy of Sciences of the United States of America 114(23):5952-5957.

Lee GA, Crawford GW, Liu L, Chen XC. 2007. Plant and people from the early Neolithic to Shang periods in North China. Proceedings of the National Academy of Sciences of the United States of America 104:1087-1092.

Lee HF, Zhang DD, Pei Q, Jia X, Yue RPH. 2017. Quantitative analysis of the impact of droughts and floods on internal wars in China over the last 500 years. Science China Earth Sciences 60:2078-2088.

Lee HF. 2018. Internal wars in history: Triggered by natural disasters or socio-ecological catastrophes? The Holocene 28:1071-1081.

Lev-Yadun S, Gopher A, Abbo S. 2000. The cradle of agriculture. Science 288: 1062-1063.

Li BC. 1997. Ancient cities remains Gansu in province. Archaeology and Cultural Relics 60-64. In Chinese.

Li XQ, Sun N, Dodson J, JM, Zhao KL, Zhou XY. 2011. The impact of early smelting on the environment of Huoshiliang in
Hexi Corridor, NW China, as recorded by fossil charcoal and chemical elements. Palaeogeography, Palaeoclimatology, Palaeoecology 305:329-336.

Liu FW, Yang YS, Shi ZL, Storozum MJ, Dong GH. 2018. Human settlement and wood utilization along the mainstream of Heihe River basin, northwest China in historical period. Quaternary International. doi: 10.1016/j.quaint. 2018.05.033.

Li ZX. 1995. Research of ancient cities in Qinghai Province. Xi'an: Northwest University Press.

Long TW, Wagner MK, Demske D, Leipe C, Tarasov PE. 2017. Cannabis in Eurasia: origin of human use and Bronze Age trans-continental connections. Vegetation History Archaeobotany 26:245-258.

Lu HY, Zhang JP, Kam-biu Liu, Wu NQ, Li YM, Zhou KS, Ye ML, Zhang TY, Zhang HJ, Yang XY, Shen LC, Xu DK, Li Q. 2009. Earliest domestication of common millet in East Asia extended to 10000 years ago. Proceedings of the National Academy of Sciences of the United States of America 106:7363-7372.

Ma MM, Dong GH, Jia X, Wang H, Cui YF, Chen FH. 2016. Dietary shift after 3600 cal yr BP and its influencing factors in northwestern China: Evidence from stable isotopes. Quaternary Science Reviews 145:57-70.

Ma MM, Dong GH, Lightfoot E, Wang H, Liu XY, Jia X, Zhang KR, Chen FH. 2014. Stable isotope analysis of human and faunal remains in the western Loess Plateau, approximately $2000 \mathrm{cal}$ BC. Archaeometry 56:237-255.

Ma MM, Dong GH, Liu XY, Lightfoot E, Chen FH, Wang H, Li H, Jones MK. 2013. Stable isotope analysis of human and animal remains at the Qijiaping site in middle Gansu, China. International Journal of Osteoarchaeology 25:215-219.

Ma SZ. 1998. The history and culture of ancient state in central China. Zhengzhou: Daxiang Press. p. 1-477. In Chinese.

Marcott SA, Shakun JD, Clark PU, Mix AC. 2013. A reconstruction of regional and global temperature for the past 11300 years. Science 33:1433-1444.

Medina-Elizalde M, Rohling E J. 2012. Collapse of classic Maya civilization related to modest reduction in precipitation. Science 335:956-959.

Mischke S, Zhang CJ. 2010. Holocene cold events on the Tibetan Plateau. Global Planet Change 72:155-163

Pu CF, Pang YX. 1990. Remains of the Shajing culture at Sanjiao ancient city and Hamadun of Yongchang, Gansu. Acta Archaeologica Sinica 2:205-237. In Chinese.

Qian YP. 2000. Research on prehistoric walled-town sites and the origins of civilization in China. Xian: Northwest University Press. In Chinese. 
Qiu SJ, Yao YB. 2003. The distribution and function of ancient cities in China. Collections of Essays on Chinese Historical Geography 18:100-106. In Chinese

Redfield R, Singer MB. 1954. The cultural role of cities. Economic Development and Cultural Change 3:53-73.

Reimer PJ, Bard E, Bayliss A, Beck JW, Blackwell PG, Bronk RC, Buck CE, Cheng H, Edwards RL, Friedrich M, Grootes PM, Guilderson TP, Haflidason $\mathrm{H}$, Irka $\mathrm{H}$, Hatte $\mathrm{C}$, Heaton $\mathrm{TJ}$, Hoffmann D, Hogg AG, Hughen KA, Kaiser KF, Kromer B, Manning S W, Niu M, Reimer RW, Richards DA, Scott EM, Southon JR, Staff RA, Turney CSM, Van der Plicht J. 2013. IntCal13 and Marine13 radiocarbon age calibration curves $0-50,000$ years cal BP. Radiocarbon 55:1869-1887.

Schiffer MB. 1986. Radiocarbon dating and the "old wood" problem: the case of the Hohokam chronology. Journal of Archaeological Sciences 13:13-30.

Shao HQ. 2012. Discussion on the utilization of radiocarbon dates in archaeology. World of Antiquity 41-43. In Chinese

Shen J, Liu XQ, Wang SM, Matsumoto R. 2005. Palaeoclimatic changes in the Qinghai Lake area during the last 18000 Years. Quaternary International 136:131-140

Staubwasser M, Sirocko F, Grootes PM, Segl M. 2003. Climate change at the $4.2 \mathrm{ka}$ BP termination of the Indus valley civilization and Holocene south Asian monsoon variability. Geophysical Research Letters 30.

Sun GQ. 1990. The Chinese prehistoric walled sites and ancient civilization. Cultural Relics of Central China 2:49-64. In Chinese.

Sun N, Li XQ, Zhou XY. 2010. Early smelting recorded by charcoal fossils in Hexi corridor, Gansu Province-An environment influence factor. Quaternary Sciences 30:319-325. In Chinese.

Thiébault S. 2002. Charcoal analysis: methodological approaches, Palaeoecological results and wood uses. In: Proceedings of the Second International Meeting of Anthracology, Paris, September 2000. British Archaeological Reports Limited.

Wang SZ, Li H, Zhang LR, Chen GK, Wang P, Zhao ZJ. 2014. Tree exploitation and Palaeoenvironment at Heishuiguo Xichengyi site, Zhangye city, Gansu Province-revealed with excavated charcoal analysis. Quaternary Sciences 34: 43-50. In Chinese.

Wang SZ, Wang QQ, Wang ZX, Liang GJ, Qi WY, Ren XY. 2016. The utilization and the ecological environment indicated by charcoal remains in Jinchankou site during middle and late Qijia culture. Agricultural Archaeology 1:9-15. In Chinese.

Wang ZZ. 1995. Review and thinking about the origin of the ancient civilization. Trends of Recent Researches on The History of China 2:2-6. In Chinese.

Wanger M, Tarasov P, Hoisner D, Fleck A, Ehrich R, Chen XC, Leipe C. 2013. Mapping of the spatial and temporal distribution of archaeological sites of northern China during the Neolithic and Bronze Age. Quaternary International 344-357.

Watson W. 1971. Cultural frontiers in Ancient East Asia. Edinburgh: Edinburgh University Press.

Weiss H, Courty MA, Wetterstrom W, Guichard F, Senior L, Meadow R, Curnow A. 1993. The genesis and collapse of third millennium north Mesopotamian civilization. Science 261:995-1004

Wu QZ. 2002. The historical experience and lessons of the flood control in ancient China. City Planning Review 4:021. In Chinese

Xie DJ. 2002. Prehistoric archaeology in GansuQinghai. Beijing: Cultural Relics Publishing House Press. In Chinese.

$\mathrm{Xu} \mathrm{H.} \mathrm{2009.} \mathrm{Ancient} \mathrm{cities} \mathrm{(towns)} \mathrm{is} \mathrm{the} \mathrm{only} \mathrm{sign} \mathrm{of}$ civilization era-the promotion of settlement research method about the exploration of early civilization. Journal of National Museum of China. 4:9-11. In Chinese

Yan WM. 1999. Inquiries into the dawn of Chinese Civilization: retrospection and reflection. Cutural Relics 10:27-34. In Chinese

Yang B, Qin C, Wang JL, He MH, Melvin TM, Osborn TJ, Briffa KR. 2014. A 3,500-year treering record of annual precipitation on the northeastern Tibetan Plateau. Proceedings of the National Academy of Sciences of the United States of America 111(8):2903-2908.

Yang XY, Wan ZW, Perry L, Lu HY, Wang Q, Zhao CH, Li J, Xie F, Yu J C, Cui TX, Wang T, Li MQ. Ge QS. 2012. Early millet use in north China. Proceedings of the National Academy of Sciences of the United States of America 109: 3726-3730.

Yin LK. 2002. The ex-situ Protection and the ecological adaptability of Tamarix L. in China. Arid Zone Research 19:12-16. In Chinese.

Zhang JP, Lu HY, Gu WF, Wu NQ, Zhou KS, Hu YY, Xin YJ, Wang C. 2012. Early mixed farming of millet and rice 7800 years ago in the middle Yellow River region, China. PLoS ONE 7:e52146.

Zhang XM, Shan L. 1986. Effects of Soil Drought on Physiology and Productivity of Broomcorn Millet and Foxtail Millet. Journal of Ecology 5:15-18. In Chinese.

Zhang YS, Zhao XP, Qiao L. 1999. Excavation of a Yangshao site of city in the Outskirts of 
Zhengzhou. Cultural Relics. doi:10.13619/j.cnki. cn11-1532/k.1999.07.001. In Chinese.

Zhao ZJ. 2011. New archaeobotanic data for the study of the origins of agriculture in China. Current Anthropology 52:295-306.

Zhou XY, Li XQ, Dodson J, Zhang KL, Atahan P, Sun N, Yang Q. 2012. Land degradation during the Bronze Age in Hexi Corridor
(Gansu, China). Quaternary International 254: 42-48.

Zhou XY, Li XQ, Dodson J, Zhang KL. 2016. Rapid agricultural transformation in the prehistoric Hexi corridor, China. Quaternary International 426:33-41.

Zuiderhoek A. 2016. The ancient city. London: Cambridge University Press. p. 20-36. 